\title{
Conflict in Donbass as a Case Study of the Deconstruction of Ukraine's Statehood. PresentState and Prospects for Regulating It
}

\author{
Marcin Orzechowski \\ Ph.D., Assistant Professor, University of Szczecin (Szczecin, Poland) \\ E-mail: orzechowski.martin@gmail.com \\ https://orcid.org/0000-0001-7272-6589
}

Orzechowski, Marcin (2019) Conflict in Donbass as a Case Study of the Deconstruction of Ukraine's Statehood. Present State and Prospects for Regulating It. Ukrainian Policymaker, Volume 5, 53-60. https://doi.org/10.29202/up/5/6

The subject of the article is the analysis of deconstruction of the statehood of Ukraine with special reference to the conflict in Donbas. Activities in the south-eastern part of Ukraine are part of the broader context of the Russian Federation's strategic activities in the post-Soviet area. Some analysts believe that the Russians consistently implement the strategy of neo-imperial expansionism and their activities in Donbas are the next step to reintegration of the post-Soviet area. An important role is also played by the policy implemented by the president and government of Ukraine.

The author verifies three research hypotheses: (1) that the chief objectives of Russian politics are to destabilize the situation in Ukraine. (2) that Donbass conflict is an example of the use of hybrid war elements such as irregular military operations (guerrilla warfare, sabotage, subversive activities, terrorist acts) and elements of information fight, such as propaganda or disinformation, be it economic or digital. (3) that the non-military methods of propaganda are helping to create a proper propaganda apparatus and the activation of "agitators" who would do "the field work" involving the exposure of the most attractive aspects of "Russianness".

Keywords: International relations, Russian Federation, Ukraine, political strategy, neo-imperial expansionism, conflict in Donbas

Received: August 12, 2019; accepted: September 10, 2019

(C) Orzechowski, Marcin, 2019 


\section{Introduction}

The subject of the analysis in this paper involves the activities of the Russian Federation undertaken in the post-Soviet region. The south-eastern part of Ukraine is presented as a case study, but the specificity of Russia's actions de facto refers to the entire area of the Union of Soviet Socialist Republics (the USSR). After Transnistria, Abkhazia and South Ossetia, Donbas is yet another "hot spot" in the post-Soviet space enabling Russia to destabilize the situation in the region and to meddle in the internal affairs of other countries (Furier, 2014). As the starting point for the analysis, the author assumed that the actions destabilizing the situation in the region constitute an element of the strategy of the Russian Federation's neoimperialist expansionism, which has been consistently implemented for some time now. The field of the strategy implementation is the area invariably considered by the Russians as their exclusive sphere of influence, which results in the intensification of the activities aiming at the deconstruction of political systems of former union republics (Moldova, Georgia, and Ukraine).

In this paper, the author verified the following research hypotheses. First one that the chief objectives of Russian politics is destabilizing the situation in Ukraine and incorporating two autonomous political entities controlled by Russia into the Ukrainian political system, which does not necessarily need to result in the creation of a new state commonly known as Novorossia. Weakening Ukraine and its position in the region enough to effectively discourage the western states from undertaking any actions aimed at tightening mutual relations with that state would be considered as a more important goal from the standpoint of Russia's strategic interests.

Second hypotheses, that the conflict in Donbas shows the signs of a phenomenon known as hybrid warfare, constituting a sort of "a blend" of classically military methods - above all of irregular military operations (guerrilla warfare, sabotage, subversive activities, terrorist acts) and elements of information fight, such as propaganda or disinformation, be it economic or digital (Bachman \& Gunneriuson, 2014). The concept of "Malorussia", sometimes also described as "Novorossia", became an element of the political propaganda in the mass media, but also a scientific theory of sorts (Nieczypor, 2010).

Third hypotheses, that in the event of a conflict in the east of Ukraine we are faced with a territorial dimension of hybrid warfare. Non-military methods of propaganda employed by Russia refer in particular to the nation state as well as traditional ethic, clan or tribe communities permanently residing in a given territory (Gruszczak, 2016). Therefore, they are an element of informational fight aiming to create a proper propaganda apparatus and the activation of the so-called "agitators" who would do "the field work" involving the exposure of the most attractive aspects of "Russianness". It seems that in practice it would mean making Novorossia a part of "the Russian world", to which the president of the Russian Federation - Vladimir Putin — referred to on numerous occasions (Orzechowski, 2017). Therefore, the main goal of these types of actions is extending and maintaining jurisdiction and administrative control over a given area, protecting the borders delineating the limits of such jurisdiction, enforcing systemic rules and legal norms in relation to the population residing in a given area, ensuring public order, managing natural resources and business activity. All those elements share one common characteristic, namely they ought to destabilize the socio-political system in the country in the territory of which this conflict is being played out. 
The structure adopted in the paper aims to ensure the transparency and complementarity of the presented argument, while the applied research methods include: systemic, historical, institutional and legal as well as prognostic analyses.

\section{Some remarks regarding the specific nature of the strategy of the Russian Federation's neo-imperialist expansionism in the post-Soviet region}

The phenomenon of a political strategy became the subject of scientific study, which in a way forced the expansion of the spectrum of research approaches to the analysed problem. One of them is the analysis of a political strategy as multi-faceted actions carried out by a state on the international arena. The interpretation of the phenomenon of strategy is a long-term task, which becomes a sort of a guideline for the steps taken in foreign policy. It emphasises that a strategy has a national character and similarly as politics, to which it is subordinated, it extensively takes into consideration the neighbourhood, thus the entire spectrum of political, economic and military conditions, which makes it "the grand strategy". Henry Kissinger also uses the term of "strategy" in its narrower meaning — in the sense of a military potential. Therefore, a strategy encompasses this part of politics in which a military instrument is used to ensure national security (Orzechowski, 2015).

The specificity of the Russian Federation's political strategies in the post-Soviet region comes down to the fact that, despite the evolution of those strategies, they have maintained certain continuous, permanent, timeless elements. Such elements refer to the historical experiences of a given state and the psychological sphere, in which the perception of Russia as a superpower plays an exceptionally important role. It particularly refers to the region of Eastern Europe, which the Russians believe to remain "an invariable territory of influence and pursuit of major Russian interests", but it in fact encompasses the entire post-Soviet territory (Orzechowski, 2015).

When analysing the conditions motivating the Russian Federation to take steps based on the strategy of neo-imperialist expansionism, the following conclusions can be drawn: first of all, after the collapse of the Union of Soviet Socialist Republics, Russia lost significant influence in the former union territories. In this case, influence is understood as propaganda and pressure exerted by oligarchs and the representatives of the political establishment on individuals, organisations or authorities of the states that used to be part of the Soviet Union. All that puts Russia in a position in which it needs to rebuild its influence in the post-Soviet territory, both for propaganda and for strictly political reasons (Brooke, 2012).

Secondly, it needs to be remembered that in the 1990's the area of former Soviet influence became the space of West European countries' economic expansion, and what is even worse, a gradual growth of the North Atlantic Treaty Organization through the accession of Central European countries was a highly painful process of "appropriation" of the Russian sphere of influence. Therefore, every effort needed to be made in order to put a stop to those events and to the presence of NATO forces in the territory of Eastern Europe.

Thirdly, because of the present situation, the influences of Russian oligarchs and entrepreneurs have decreased as well. It was a highly unfavourable situation from the point of the Russian Federation's strategic interests in the post-Soviet territories. Informal political and business ties were used on many occasions for the purpose of pushing through the economic and political actions favourable to Russia, not only in Ukraine. 


\section{Implications of the conflict in Donbas for the statehood in Ukraine}

The process of statehood deconstruction may assume various forms. In Ukraine, we deal with the use of elements of informational warfare and hybrid warfare, which would effectively destabilize the political and social situation in that country. The events in Donbas may serve as a contemporary example of an attempt at dismantling state integrity. An effective attempt, since its purpose was in fact the detachment of a part of the territory from the motherland, it needs to be concluded that the intention was successfully achieved. In turn, the issue de jure affiliation of the Donetsk and Lugansk Republics remains unresolved, since two entities: a state one and quasi-state one recognize them as their own part or a political territory (Orzechowski, 2016).

Following the annexation of Crimea and the intensification of Donbas conflict as a result of the sanctions imposed on Russia by the western states, a drop in investments occurred even in the sectors such as agriculture, which received assistance from the government, inter alia, through the protection against foreign competition. Therefore, the reinstatement of the full Russian Federation's voting rights in the Parliamentary Assembly of the Council of Europe (PACE) was an exceptionally important achievement (Klein, 2014). On 17 May 2019, the Council of Europe's Committee of Ministers took this exact decision, which is the key decision-making authority of that organization. A document of the Council of Ministers constitutes Moscow's political success, since the reinstatement of its full rights, as a Council of Europe Member will occur without any Russia making any concessions, including the modification of the aggressive politics against Ukraine. Representatives of German authorities assure that Russia's return to the Council of Europe is not the first step towards lifting the western sanctions imposed on Russia on account of its aggression against Ukraine. That decision enabled the Russian party to fortify its conviction that any concessions regarding the support to separatists in Donbas are unnecessary, which may significantly hinder the conflict resolution.

The above-mentioned reasons became "the driving force" behind the implementation of the neo-imperialist expansionism strategy, while the involvement in the conflict in Donbas and the support provided to the separatist People's Republics of Donetsk and Lugansk became an element of the process of reinstating the unity of "the Russian nation" within the scope of a strict integration block (the Eurasian Economic Union), or even a state organization (light USSR) (Krepinevich, 2017). “The Russian world”(Russkij Mir) became not merely a visionary motive surfacing in the propaganda used by the political establishment and the mass media in Russia, but also a scientific theory, according to which the "anti-Russian Ukrainian nationalism, holding a huge mobilisation potential and its own mythology and understanding of the world" must be combated using all means (Orzechowski, 2015). Therefore, the issue regarding human rights of the Russian-speaking population residing outside of the Russian Federation borders is among major factors justifying the actions undertaken by Russia in the Crimea. The Russians eagerly invoke such conceptual categories as national interest, truth and justice in order to legitimize its politics, as well as the use of military force as a justified tool of protecting their countrymen abroad.

An unstable internal situation, evidenced by the Euromaidan and a fairly dichotomous social division - a part of Eastern Ukraine opposing the Revolution of Dignity, i.e. supporters of the so-called anti-Maidan, as well as a part of Western Ukraine supporting the toppling of president Victor Yanukovych — was yet another favourable contribution from the point of view of Russia's strategic interests. Due to economic problems, corruption affecting not only business but also politics, which in eastern-bloc countries frequently provides opportunities 
for business development, makes it easier to incite extreme social attitudes, which owing to emotional load, negatively affect the objective assessment of the events.

Recapitulating the considerations undertaken in this part of the article, it needs to be concluded that all of the above-specified elements contribute to a cohesive picture of strategic actions concerning Russian domination in the post-Soviet territory. The main objective is the need for reinstatement of the unity of "the Russian nation", at times also defined as "a Russianspeaking community", whereas the instrument for achieving it is an attempt at reintegration of the post-Soviet territory, e.g. in the framework of the Eurasian Economic Union, or through the creation of a state organism, encompassing at least a part of that territory. It is on the basis of the analysed community of "the Russian world" that the priority political project under the name of the Eurasian Economic Union is being implemented (Menkiszak, 2014). Hence, it can be treated as a plan of transformation of the above-mentioned organization into a strict integration bloc, partially mimicking the European Union in its form, however realizing a different development model than the one implemented in the West. However, one fact remains constant, namely that the assuming a strategic control over Ukraine still remains crucial to the success of Russian plans.

After winning the presidential elections in Ukraine, VolodimirZelensky brought about a significant mobilization of international negotiations regarding Donbas, which arose from the fact that the conclusion of the war was one of the key points of his political platform. During the campaign and after his taking of the office of the president, he promised on a number of occasions that he would be striving towards a speedy resolution of the conflict. At the same time, he was emphasising that Ukraine could not permit the present situation in the east of the country to last for the subsequent years. Public polls conducted in the course of the pending presidential campaign unequivocally demonstrated that the majority of respondents participating in the poll found that the problem requiring the most urgent resolution concerned bringing peace to Donbas $(65 \%)$, which was deemed as a more significant issue that the improvement of the economic situation (39\%) and combating corruption (33\%) (Konończuk, 2019).

Over the last three months, Ukrainian diplomacy has significantly activated its contacts with Germany and France, the key states in Kiev's European policy. The new president's first foreign visits were to Brussels, Paris and Berlin, which arose from the need to ensure political support for hammering out a compromise with Russia. During that time the Ukraine's president had four telephone conversations with Chancellor Angela Merkel and three telephone conversations with President Emmanuel Macron. Moreover, several meetings have been held between the representatives of Ukraine and the American administration (inter alia, Zelensky's meeting with the USA's Vice-President Michael Pence in Warsaw and with the national security adviser John Bolton in Kiev) (Konończuk, 2019).

The steps taken by Kyiv on the international arena as well as visible softening of the new authorities' rhetoric towards Russia confirmed that Zelensky is keen to quickly regulate the situation in Donbas. Russian authorities are aware that the president of Ukraine is under pressure of his own promises. Ensuring that the constitution of Ukraine guarantees a special and permanent status to that region within the framework of the Ukrainian state became a crucial issue for Russia. Donbas autonomy would constitute a part of the process of Ukraine's decentralization. It would be accompanied by the legitimization of the separatists controlled by Moscow through the organization of elections in the region under international supervision. It would actually mean that Moscow would in fact maintain its control over Donbas and thus it 
would be able to influence Ukraine's politics. At the same time, Russia is interested in achieving progress in the conflict resolution, provided that it would occur on its own terms, since it would result in softening of the western sanctions. What is significant from the Russian standpoint, the postulated peace process would not encompass the Crimea, whose status, according to Moscow, is not subject to any negotiations.

An exchange of prisoners of war that occurred on September 7, 2019 doubtlessly provided a breakthrough in mutual relations. After many months of negotiations, prisoners were exchanged between Russia and Ukraine, involving 35 individuals on either side. The prisoners freed by Russia included the most famous political prisoners. One of them is Oleg Sentsow, a Ukrainian director, arrested in 2014 in the Crimea, and then sentenced by a Russian court to the penalty of 20 years of imprisonment for "terrorist activity in the territory of the Crimea" (Strzelecki, 2019). Furthermore, 24 Ukrainian seamen were freed, who had been apprehended after the conflict in the Kerch Strait that had taken place on 25 November 2018, when Ukrainian vessels had been fired upon and detained by Russian warships.

The consent to the prisoners exchange was meant to demonstrate Moscow's constructive attitude and assure the favour of French and German leaders in the face of negotiations concerning the future of Donbas as well as the debate in the UE regarding the future of the sanctions. However, Moscow's agreement to the prisoners exchange does not mean that Russia is prepared to offer concessions to Kiev in any key political issues regarding the status of Donbas and Crimea. As already mentioned, Kremlin's strategy was to force Ukraine to decentralize and to grant autonomy to Donbas within the framework of Ukrainian state, which would translate into a greater number of instruments of Moscow's influence in all of Ukraine, with a simultaneous acceptance of this formula obtained within the scope of a scheduled meeting, held for the first time in three years, of the so-called Normandy format leaders (France, Germany, Russia, Ukraine), which could consequently lead to softening of western sanctions towards the Russian Federation.

Bringing about the prisoners exchange must be recognized as a doubtless success of President VolodymirZelensky, who thus demonstrated that he is able to successfully conduct negotiations with Russia. Zelensky expected that in this way he could accelerate an agreement with Moscow on ending hostilities, which, as previously mentioned, would constitute the fulfilment of one of his major pre-election promises. If any real progress were achieved in the peace process, the main risk faced by the new authorities in Ukraine would be the reaction of Ukraine's society. If any possible concessions to Russia are treated by Zelensky's electorate, including by the veterans of Donbas conflict, as treason, it could lead to a deep internal crisis.

\section{Conclusions}

All the actions undertaken by the Russian Federation towards Ukraine within the scope of the implementation of neo-imperialist expansionism strategy can be divided into those occurring at an international level and at the level of the Ukraine's internal political system. The international scope chiefly entails: disturbing the process of economic and political support of the western countries for the authorities in Kyiv and strengthening conflicts between various political forces, ethnic or social groups against the background of current and historical events in the countries directly neighbouring Ukraine. Furthermore, it seems extremely important that support is provided to various kinds of organizational and political structures aiming at the development of Ukraine's negative image in the world and at the 
increase of international pressure on the state, which will be used by the pro-Russian forces in Ukraine to further destabilize the country. Actions performed at this level may also involve various attacks against the Ukrainian diaspora, inter alia, through the employment of antiimmigration and xenophobic rhetoric.

The actions occurring within the Ukraine's internal political system include: inciting distrust towards the authorities among a significant proportion of the Ukrainian society through propaganda messages broadcast by the media reporting on the economic and financial problems existing in the political and social spheres as well as on the slow pace or ineffectiveness of reforms, particularly the ones related to anti-corruption activities. Inspiring, escalating and strengthening divisions of religious and faith-related nature seems to be equally significant, particularly the division between the Orthodox Church of Moscow Patriarchate and the Ukrainian Orthodox Church - Kyiv Patriarchate, which may result in deepening Ukraine's destabilization also in the sphere of values and beliefs.

Thanks to modern technologies, propaganda, and IT infrastructure destabilization and through conventional military attacks, the Russian Federation intentionally and systematically undertakes to destabilize the state on the Dnieper.

The actions of the Russian Federation towards Ukraine are multi-faceted and they result in the effective destruction of the opponent on multiple planes: military, economic, political, informational and identity-related plane. The analysis conducted for the purpose of this paper allows the author to positively verify the research hypotheses formulated in the introduction.

\section{References}

Bachman, Sasha, and Hakan Gunneriusson. (2014) Terrorism and Cyber Attacks as Hybrid Threats: Defining a Comprehensive Approach for Countering $21^{\text {st }}$ Century Threats to Global Peace and Security. The Journal on Terrorism and Security Analysys, Spring 2014， $9^{\text {th }}$ Edition, 02.04.2014. URL:http://eprints.bournemouth.ac.uk/21206/1/ Terrorism_and_Cyber_Attacks.pdf. [Accessed: 10.05.2016].

Brooke, James. (2012) Is 'Soviet Union light' the Future of Putin's Russia? Europe, 05.10.2012. http://www.voanews.com/content/soviet-union-light-future-putinrussia/1521341.html

Furier, Andrzej. (2014) Koncepcja metodologiczna Aleksandra Dugina w badaniachelitkaukaskich — próbaim plementacji. Bodio Tadeusz (eds.) Kaukaz Pótnocny: elity, reżimy, etnopolityka, bezpieczeństwo. Wydawnictwo Aspra, Warszawa. 45-73.

Gruszczak, Artur. (2011) Hybrydowoś ćwspólczesnych wojen — analiza krytyczna. https:// www.bbn.gov.pl/download/1/8755/Hybrydowos analiza_krytyczna.pdf [Accessed: 11.06.2017].

Grzegorz, Klein. (2014) Polityka Rosji wobec „bliskiej zagranicy” — rosyjski realizm jako zagrożenie dla bezpieczeństwa międzynarodowego. Obronność. Zeszytynaukowe, $\mathrm{Nr} 13$ (11), s. 13.

Konończuk Wojciech, (2019) Nowe nadzieje, stare ryzyka: perspektywy uregulowania konfliktu w Donbasie, Analizy OSW, 2019-09-04. https://www.osw.waw.pl/pl/publikacje/ analizy/2019-09-04/nowe-nadzieje-stare-ryzyka-perspektywy-uregulowaniakonfliktu-w [Accessed: 19.09.2019].

Krepinevich, Andrew. (2017) Preserving the balance: A U.S. Eurasia Defence Strategy, URL: 
http://csbaonline.org/research/publications/preserving-the-balance-a-u.s.-eurasiadefense-strategy [Accessed: 16.05.2017].

Menkiszak, Marek. (2014) Doktryna Putina: Tworzenie koncepcyjnych podstaw rosyjskiej dominacji na obszarze postradzieckim, Komentarze OSW, 27.03.2014. URL:http:// www.osw.waw.pl/pl/publikacje/komentarze-osw/2014-03-27/doktryna-putinatworzenie-koncepcyjnych-podstaw-rosyjskiej [Accessed:24.04.2015].

Nieczypor, Krzysztof. (2010) Ukraina: od Ukrainy do Małorosji, 02.06.2010. — URL:http:// eastbook.eu/2010/06/country/ukraine/ukraina-od-ukrainy-do-malorosji/ [Accessed: 04.02.2015].

Orzechowski, Marcin. (2015) Od realnego pragmatyzmu do neoimperialistycznego ekspansjonizmu. Ewolucja strategii politycznej Federacji Rosyjskiej wobec Ukrainy, WydawnictwoVolumina, Szczecin.

Orzechowski, Marcin. (2016) Wojna hybrydowa jako przejaw neoimperialnego ekspansjonizmu w strategii politycznej Federacji Rosyjskiej wobec Ukrainy. TEKA Komisji Politologiii Stosunków Międzynarodowych. Nr 11/3, 165-180.

Orzechowski, Marcin. (2017) Koncepcja walki informacyjnej jako element strategii bezpieczeństwa Federacji Rosyjskiej. Wojna w Donbasie jako case study zastosowania elementów walkiin formacyjnej, 25.05.2017. — URL:https://repozytorium.uph.edu. pl/bitstream/handle/11331/1132/Orzechowski.M_Koncepcja_walki_informacyjnej. pdf? sequence $=1$ [Accessed: 25.05.2017].

Shynkarenko, Oleg. (2014) Russia's hybrid war in Ukraine, Institute for War \& Peace Reporting, 17.09.2014 — URL:https://iwpr.net/global-voices/russias-hybrid-warukraine [Accessed: 21.12.2014].

Strzelecki, Jan. (2019) Wymiana więźniów pomiędzy Rosją a Ukraina, Analizy OSW, 2019-0909. https://www.osw.waw.pl/pl/publikacje/analizy/2019-09-09/wymiana-wiezniowpomiedzy-rosja-a-ukraina 